\title{
Emergence of Zika Virus Epidemic and the National Response in Jamaica
}

\author{
KR Webster-Kerr ${ }^{1}$, CDC Christie ${ }^{2}$, A Grant ${ }^{1}$, D Chin ${ }^{1}$, H Burrowes $^{1}$, K Clarke ${ }^{1}$, I Wellington ${ }^{1}$, K Shaw ${ }^{1}$, W De La Haye ${ }^{1}$
}

\section{ABSTRACT}

Background: Jamaica, along with the Americas, experienced major epidemics of arboviral diseases transmitted by the Aedes aegypti mosquito in recent years. These include dengue fever in 2012, Chikungunya fever in 2014 and Zika virus infection (ZIKV) in 2016. We present the emergence of the ZIKV epidemic in Jamaica and outline the national response.

Methods: The Ministry of Health's preparedness included: heightened surveillance, clinical management guidance, vector control and management, laboratory capacity strengthening, training and staffing, risk communication and public education, social mobilization, inter-sectoral collaboration, resource mobilization and international cooperation.

Results: The first case of ZIKV was confirmed on January 29, 2016 with date of onset of January 17, 2016. From January 3 to July 30, 2016 (Epidemiological Week (EW) 1-30), 4648 cases of ZIKV were recorded (4576 suspected, 72 laboratory-confirmed). Leading symptoms were similar among suspected and confirmed cases: rash (71\% and 88\%), fever (65\% and 53\%) and joint pains (47\% and $38 \%)$. There were 17 suspected cases of Guillain Barre syndrome; 383 were reported in pregnant women, with no reports of microcephaly to date. Zika and dengue viruses were circulating predominantly in 2016. At EW30, 1744 cases of dengue were recorded (1661 suspected and 83 confirmed). Dengue serotypes 3 and 4 were circulating with 121 reports of dengue haemorrhagic fever.

Conclusion: The possibility exists for endemicity of ZIKV similar to dengue and chikungunya in Jamaica. A ZIKV vaccine, similar to the dengue and chikungunya vaccines, is needed to be fast-tracked into clinical trials to mitigate the effects of this disease.

Keywords: Chikungunya, dengue, epidemic, Guillain-Barré syndrome, Jamaica, microcephaly, pregnancy, Zika virus

\section{La Aparición de la Epidemia del Virus del Zika y la Respuesta Nacional en Jamaica} KR Webster-Kerr ${ }^{1}$, CDC Christie ${ }^{2}$, A Grant ${ }^{1}$, D Chin ${ }^{1}$, H Burrowes $^{1}$, K Clarke ${ }^{1}$, I Wellington ${ }^{1}$, K Shaw ${ }^{1}$, W De La Haye ${ }^{1}$

\section{RESUMEN}

\begin{abstract}
Antecedentes: Jamaica, junto con el resto de las Américas, experimentó grandes epidemias de enfermedades arbovirales transmitidas por el mosquito Aedes aegypti en los últimos años. Estas incluyeron la fiebre del dengue en 2012, la fiebre de chikungunya en 2014, y la infección por el virus del Zika (ZIKV) en 2016. Aqui presentamos la aparición de la epidemia del ZIKV en Jamaica y hacemos un bosquejo de la respuesta nacional.

Métodos: La preparación del Ministerio de Salud incluyó las siguientes medidas: intensificación de la vigilancia, guía para el tratamiento clínico, manejo y control de vectores, fortalecimiento de la capacidad de laboratorio, capacitación y dotación de personal, comunicación de riesgos y educación pública, movilización social, colaboración intersectorial, movilización de recursos y cooperación internacional. Resultados: El primer caso de ZIKV fue confirmado el 29 de enero de 2016 con fecha de inicio de 17 de enero de 2016. Desde el 3 de enero al 30 de julio de 2016 (semana epidemiológica (SE) 1-30), se registraron 4648 casos de ZIKV (4576 sospechosos, 72 confirmados por el laboratorio). Los síntomas principales fueron similares entre los casos confirmados y los sospechosos: erupción ( $71 \%$ y $88 \%$ ), fiebre (65\% y 53\%) y dolores en las articulaciones (47\% y 38\%). Hubo 17 casos sospechosos de sindrome de Guillain-Barré; 383 se reportaron en las mujeres embarazadas, sin reportes de microcefalia hasta la fecha. Los virus del Zika y dengue circularon predominante en 2016. En la SE30, se registraron 1744
\end{abstract}

From: ${ }^{1}$ Ministry of Health, Kingston, Jamaica, ${ }^{2}$ Department of Child and Adolescent Health, The University of the West Indies, Mona, Kingston 7, Jamaica.
Correspondence: Dr K Webster-Kerr, Ministry of Health, 24-26 Grenada Crescent, Kingston 5. E-mail: websterk@moh.gov.jm; kwebsterkerr@yahoo.com 
casos de dengue (1661 casos sospechosos y 83 confirmados). Los serotipos de dengue 3 y 4 estuvieron circulando, produciéndose 121 reportes de fiebre de dengue hemorrágico.

Conclusión: Existe la posibilidad de que el ZIKV adquiera un carácter endémico similar al del dengue y la chikungunya en Jamaica. Se necesita someter rápidamente a prueba en ensayos clínicos, una vacuna de ZIKV similar a las vacunas contra el dengue y la chikungunya, con el fin de mitigar los efectos de esta enfermedad.

Palabras claves: Chikungunya, fiebre del dengue, epidemia, síndrome de Guillain-Barré, Jamaica, microcefalia, embarazo, virus del Zika

West Indian Med J 2016; 65 (1): 244

\section{BACKGROUND}

Zika virus (ZIKV) is an RNA virus of the family Flaviviridae to which also belong dengue, West Nile and Yellow Fever viruses (1). Zika virus is most commonly transmitted by a bite of the Aedes species of mosquitoes with Aedes aegypti implicated as the primary vector (1). Other modes of transmission include mother-to-fetus, sexual, blood and other body fluids (2). Four out of every five cases of ZIKV infection may be asymptomatic $(1,2)$. When symptoms occur, these include low-grade fever, rash, arthralgia, myalgia, fatigue, headache and conjunctivitis (1).

Before 2015, outbreaks were primarily reported in Africa, Asia and the Pacific Islands (1). An outbreak of over one million cases associated with an apparent increase in cases of Guillain-Barré syndrome and microcephaly was announced in Brazil in December 2015 and the World Health Organization (WHO) subsequently declared the spread of ZIKV a 'public health emergency of international concern' on February 1, 2016, (3). As of September 1, 2016, seventy-two countries and territories were reporting mosquito-borne ZIKV transmission, of which 55 reported a first outbreak from 2015 onwards and 46 countries in the Americas (including the United States mainland) were reporting active local transmission (4-6).

Guillain-Barré syndrome (GBS) is a 'post-infectious neurological disorder' with two-thirds of patients having symptoms of an infection occurring within the three week period prior to onset of paralysis. It is associated with Campylobacter jejuni, cytomegalovirus, Epstein Barr virus, mycoplasma pneumoniae, haemophilus pneumoniae, chikungunya and dengue virus infections and the influenza vaccine (7-10). The syndrome is identified by progressive bilateral weakness of the limbs, accompanied by an increased protein level in the cerebrospinal fluid without an attendant increase in white blood cells (7). A meta-analysis of the incidence of GBS in studies occurring in Western countries reported rates of 0.89 to 1.89 per 100000 person-years (10). Cao-Lormeau et al (2016) conducted a case-control study in which all identified cases of GBS were matched by age, gender and ethnic group to nonfebrile hospitalized cases to determine the association with ZIKV infection (11). Ninety-seven per cent (41 of 42 cases) were IgM or IgG positive for ZIKV, and $100 \%$ had neutraliz- ing antibodies, giving statistically strong association between GBS and ZIKV infection.

Microcephaly is defined as a small head circumference that is less than two standard deviations below mean levels for age and gender (12). Causes of microcephaly are multifactorial, broadly categorized as environmental or genetic, including congenital infections, prematurity and intrauterine exposure to teratogens (13). Authors from the United States Centers for Disease Control and Prevention recently concluded that "sufficient evidence has accumulated to infer a causal relationship between prenatal Zika virus infection and microcephaly and other severe brain abnormalities" (14). The evidence satisfies Shephard's criteria and the Bradford Hill criteria for proof of human teratogenicity and evidence of causation, respectively. This was established from multiple case reports and epidemiological case series which provide evidence for the "Congenital ZIKV Syndrome" similar to the fetal disruption syndrome which occurs after exposure to a fetal teratogen which is usually characterised by microcephaly, redundant scalp skin, overlapping sutures and occipital prominence (15). The established link of ZIKV to microcephaly has been confirmed in another recent publication of the first $1501 \mathrm{mi}-$ crocephaly cases reported from Brazil (16). Other perinatal complications of ZIKV include adverse pregnancy outcomes, fetal losses, amniotic fluid abnormalities, preterm delivery and intrauterine growth retardation.

Jamaica is classified as an upper middle-income developing country, the third largest island nation in the Caribbean, with a population of 2.8 million (17). The Aedes aegypti mosquito is endemic in Jamaica where unprecedented recent arboviral outbreaks have occurred as in other areas of the Americas, with epidemic dengue fever in 2012 and epidemic chikungunya fever reported in $2014(18,19)$. The national response commenced on January 29, 2016 on identification of the first case, a four-year old child who travelled back from Texas, USA with her family. As of September 9, 2016, there have been 7313 notified cases, with 5426 meeting surveillance case definitions for ZIKV and 91 cases were laboratory confirmed.

This paper describes the emergence of the ZIKV epidemic in Jamaica and outlines the national response prior to 
and during the outbreak. It describes in detail cases for EW 1-30 to allow for receipt of case notification, the return of case investigation and laboratory results.

\section{METHODS}

The Pan American Health Organization (PAHO)/World Health Organization (WHO), on May 7, 2015, issued an epidemiological alert recommending that Member States establish and maintain the capacity for ZIKV infection detection, clinical management and an effective public communication strategy to reduce the presence of the mosquito vector (20). This was based on autochthonous transmission of ZIKV in Chile and Brazil. The Ministry of Health (MOH) immediately commenced preparedness activities to include: (a) heightened surveillance b) clinical management guidance (c) vector control/ integrated vector management d) laboratory capacity strengthening (e) training and staffing (f) risk communication and public education ( $\mathrm{g}$ ) social mobilization (h) inter-sectoral collaboration (i) resource mobilization and (j) international cooperation.

The surveillance system was enhanced to identify and characterize the spread of ZIKV Infection. Zika virus infection was classified as a Class 1 notifiable disease requiring medical practitioners to notify on suspicion to the parish health department or the $\mathrm{MOH}$. The established surveillance system facilitated the further identification of ZIKV cases as presentations are similar to other Class 1 conditions including fever and rash, acute flaccid paralysis, meningitis, and to chikungunya.

The case definition in May 2015 for a suspected case was, "acute onset of fever plus any one of the following: generalized macular or papular rash, arthritis or arthralgia, nonpurulent conjunctivitis, in someone who resides in or has visited epidemic or endemic areas within two weeks prior to the onset of symptoms". The case definition was changed on November 12, 2015 to "patient with rash or elevated body temperature $\left(>37.2^{\circ} \mathrm{C}\right)$ with one or more of the following symptoms (not explained by other medical conditions): (i) arthralgia or myalgia (ii) non-purulent conjunctivitis or conjunctival hyperaemia (iii) headache or malaise", based on PAHO recommendation (21).

Confirmation of a case was based on virological identification using real time-polymerase chain reaction (RT-PCR). A presumptive diagnosis of ZIKV infection was made on IgM positive for ZIKV and negative for dengue virus.

On November 17 and December 1, 2015, PAHO/WHO informed of an increase in microcephaly in Brazil and the possible link between neurological syndromes, congenital malformations and ZIKV infection $(22,23)$. Based on the public health implications, Jamaica widened the case definition for suspected cases in December 2015 to include: (i) persons presenting with neurological manifestations possibly related to ZIKV infection, (ii) mother and child where babies were born with microcephaly and other congenital anomalies. The detection and surveillance system for congenital anomalies was enhanced by reviewing the delivery book in public hospitals as well as reporting requirements.

Pan American Health Organization, in its 2016, guidelines for surveillance of ZIKV disease and complications, recommended the new case definition for suspected ZIKV of "patient with rash with at least two or more of the following signs or symptoms: fever, usually $<38.5^{\circ} \mathrm{C}$, conjunctivitis (non-purulent/hyperaemic), arthralgia, myalgia, peri-articular oedema" (24). Jamaica has not adopted this case definition, but amended the suspected case definition for pregnant women to include rash only.

Jamaica on January 29, 2016, confirmed the first case of ZIKV infection and estimates related to ZIKV infection presentation and GBS were developed to guide the national response and mobilization of resources (Fig. 1). The following were applied: ZIKV infection risk to the population $-66 \%$; (11), ZIKV proportion of infected who are symptomatic $18.6 \%$ (25); GBS risk of 0.24/1000 ZIKV cases $(11,25)$. The estimates for Jamaica are 1782000 expected ZIKV infections of which 327888 cases would be symptomatic and approximately 428 would develop GBS (Fig. 1).

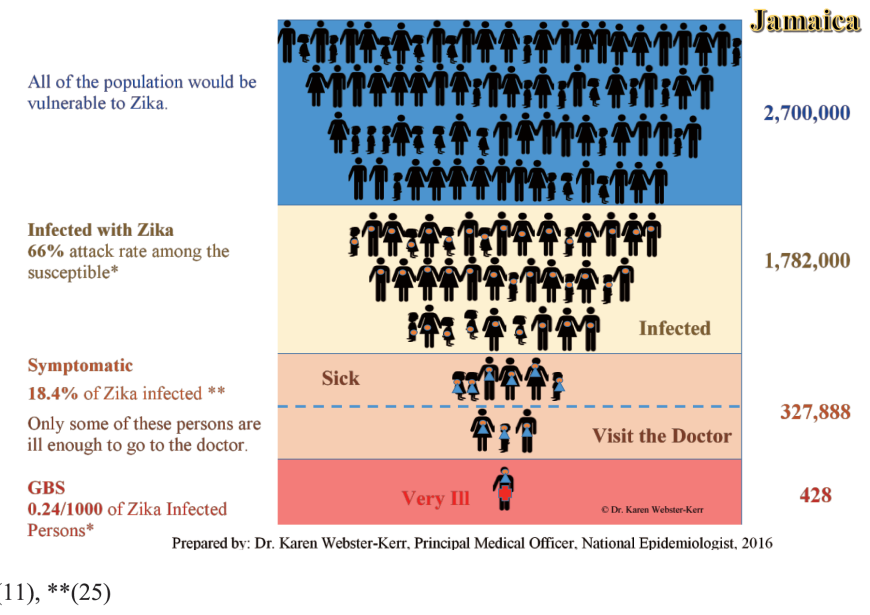

Fig. 1: Estimates for Zika Virus Infection and Guillain-Barré syndrome in Jamaica, 2016

\section{Data management}

Zika virus notification forms part of the integrated arbovirus surveillance system. Data are entered into the web-based Tryton system of the $\mathrm{MOH}$ electronic patient administrative system. Microsoft Office Excel was used in the data analysis. Geographic information system mapping was conducted using ArcGIS (10.4). Counts and proportions were used to describe the distribution of cases.

\section{RESULTS}

The first case of ZIKV virus infection was confirmed on January 29, 2016 with a date of onset on January 17, 2016. In 2016, up to September 9, 2016, the MOH received 7313 Class 1 notifications of ZIKV infections, 5426 fit the case definition and were classified as suspected. There were 91 laboratory- 
confirmed cases. Pregnant women accounted for 604 of the notifications, 521 of the suspected cases and 36 of the confirmed cases. There were 22 suspected cases of GBS, of which 15 fits level 1-3 of diagnostic certainty as defined by Brighton classification and seven were classified as GBS variants. Additionally, there was one case of meningitis in confirmed ZIKV in infection.

From epidemiological week (EW) one to week 30 (3 January 2016 to 30 July 2016), there were 4567 suspected cases and 72 confirmed cases. Based on the date of onset EW 22 had the greatest number of suspected cases (Fig. 2). With regard to GBS, there have been 17 suspected cases (14 fits level $1-3$ by Brighton classification) with the majority occurring between EW18 and EW29 (Fig 2).

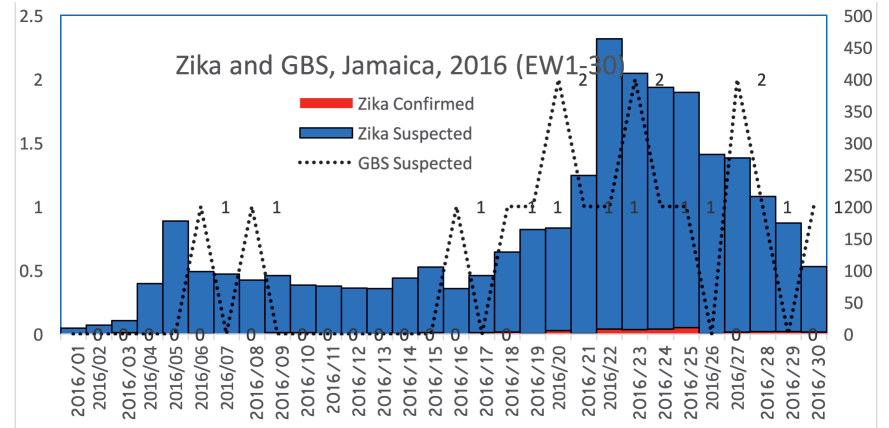

Fig. 2: Cases of Zika Virus Infection and Guillain-Barré syndrome by Epidemiological Week, Jamaica 2016

\section{Symptoms}

Leading symptoms among suspected cases were rash (71\%), fever $(65 \%)$ and joint pain (47\%). Similarly, the leading symptoms among the confirmed cases were rash (88\%), fever $(53 \%)$ and joint pain $(38 \%)$. The proportion with rash was, however, greater in the confirmed cases while the proportion with fever and joint pain was lower (Table 1).

The current PAHO case definition for a suspected case of Zika was compared to the $\mathrm{MOH}$ cases that were classified as suspected and confirmed. Among the cases that met $\mathrm{MOH}$ sus-
Table 1: Frequency of Symptoms among confirmed and suspected cases

\begin{tabular}{|c|c|c|c|c|}
\hline \multirow[t]{2}{*}{ Symptoms } & \multicolumn{2}{|c|}{ Suspected $(n=4576)$} & \multicolumn{2}{|c|}{ Confirmed $(n=72)$} \\
\hline & n & $\%$ & n & $\%$ \\
\hline Rash & 3,238 & 71 & 63 & 88 \\
\hline Fever & 2,991 & 65 & 38 & 53 \\
\hline Joint Pain & 2,158 & 47 & 27 & 38 \\
\hline Headache & 1,499 & 33 & 17 & 24 \\
\hline Conjunctivitis & 1,037 & 23 & 13 & 18 \\
\hline Muscle Pain & 610 & 13 & 8 & 11 \\
\hline Cough & 397 & 9 & 3 & 4 \\
\hline Vomiting & 366 & 8 & 1 & 1 \\
\hline Back Pain & 437 & 10 & 8 & 11 \\
\hline
\end{tabular}

pected case definition (excluding pregnant women), 33\% fit the PAHO case definition for suspected ZIKV infection. Eligibility for testing was dependent on meeting the case definition and of the 39 cases confirmed by RT-PCR, 36\% fit the PAHO case definition. In pregnant women, $85 \%$ and $94 \%$ of the $\mathrm{MOH}$ suspected and confirmed cases, respectively met the PAHO suspected case definition (Table 2).

\section{Geographic distribution}

Kingston and St Andrew (KSA) followed by St Catherine had the greatest number of suspected cases for EW 1-30, 2016, while, more recently, for the two week period EW 29-30 St James had the greatest followed by St Ann (Fig. 3a). St Thomas had the greatest number of suspected cases per population from EW1 to EW30 followed by St Catherine and KSA while for EW29 to EW30 St James followed by Trelawny and St Ann had highest number of cases per population (Fig. 3b).

\section{Arboviruses circulating in Jamaica}

Jamaica's integrated arbovirus surveillance system revealed the circulation of three arboviruses in 2016: (1) ZIKV introduced in 2016, (2) chikungunya virus and (3) dengue virus, serotypes 3 and 4, with Zika and dengue viruses predominating. Dengue was first identified in Jamaica in 1977 and over the last three decades the number of dengue cases and the frequency of outbreaks have increased.

Table 2: Comparison of PAHO suspected case definition to the $\mathrm{MOH}$ cases classified

\begin{tabular}{|c|c|c|c|c|c|c|}
\hline Case Definitions & $\begin{array}{r}\text { MOH Def } \\
\text { Suspectec }\end{array}$ & & Confirmed & & Grand Tot & \\
\hline \multirow[t]{2}{*}{ PAHO Definition } & Count & $\%$ & Count & $\%$ & Count & $\%$ \\
\hline & \multicolumn{4}{|c|}{ Excluding Pregnant Women } & & \\
\hline Does not Fit & 2,750 & 67 & 25 & 64 & 2,775 & 67 \\
\hline Fits & 1,348 & 33 & 14 & 36 & 1,362 & 33 \\
\hline \multirow[t]{2}{*}{ Total } & 4,098 & 100 & 39 & 100 & 4,137 & 100 \\
\hline & \multicolumn{3}{|c|}{ Pregnant Women } & & & \\
\hline Does not Fit & 52 & 15 & 2 & 6 & 54 & 14 \\
\hline Fits & 300 & 85 & 29 & 94 & 329 & 86 \\
\hline Total & 352 & 100 & 31 & 100 & 383 & 100 \\
\hline
\end{tabular}

Zika V in Jamaica, WIMJ Webster-Kerr Karen, et al, 19 September, 2016 


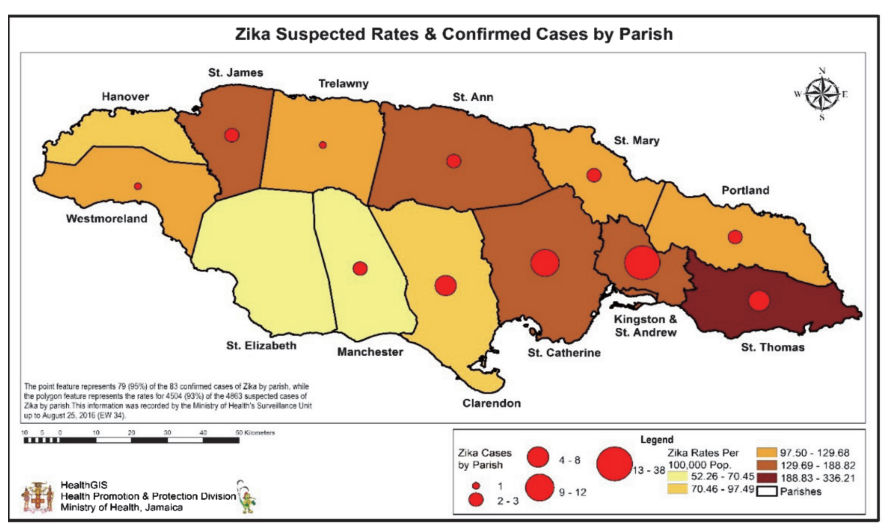

Fig. 3a: The Geographic Distribution of Suspected and Confirmed Cases of Zika

Confirmed and suspected cases of Zika virus infection up to epidemiological week 33 (week ending 20 August 2016)

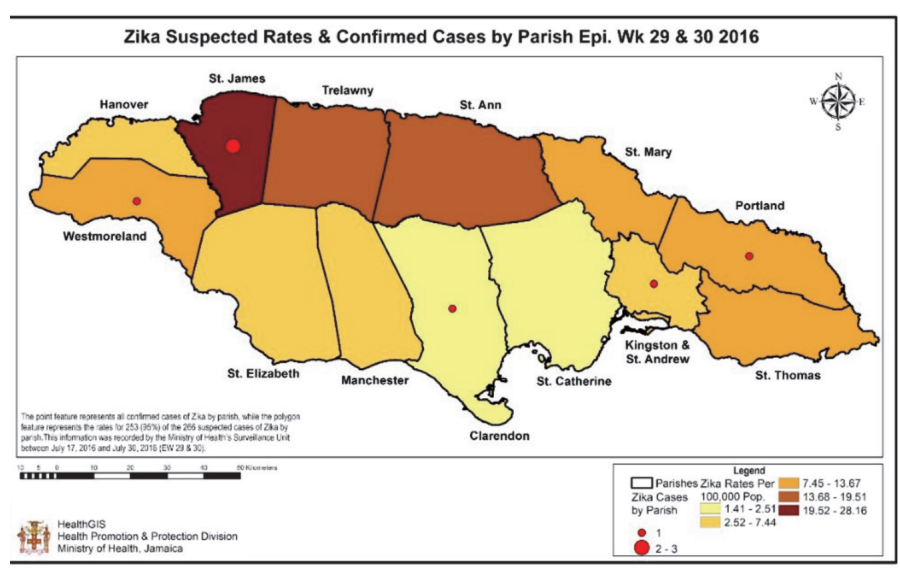

Fig. 3b: Map of the geographic distribution of suspected and confirmed cases of Zika virus Infection, Jamaica, 2016.

Confirmed and suspected cases of Zika virus infection up to Epidemiological Week 29-30 (17-30 July 2016)

At EW30, 4648 cases of ZIKV were recorded (4576 suspected, 72 confirmed) and 1744 cases of dengue (1661 suspected and 83 confirmed). Dengue serotypes 3 and 4 have been confirmed with 121 reports of dengue haemorrhagic fever.

The epidemiological curves for ZIKV and dengue showed similar patterns, however, there were more dengue confirmed in the earlier weeks of 2016 and more ZIKV confirmations in the latter weeks (Fig. 4).

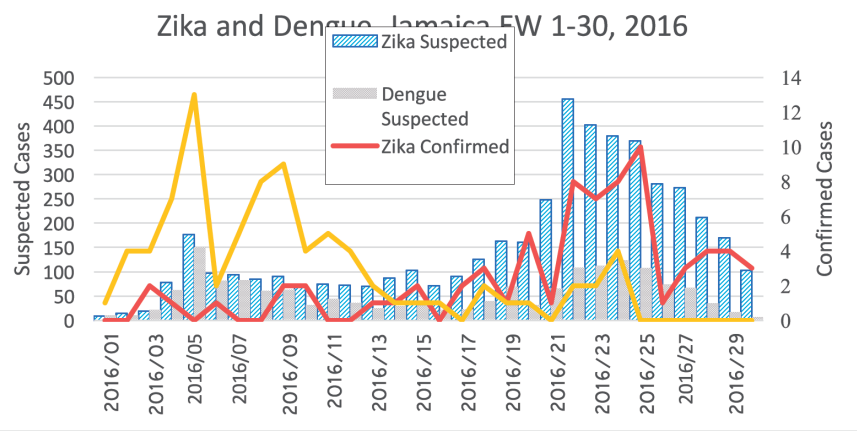

Fig. 4: Suspected and Confirmed Cases of Zika and Dengue by Epidemiological Week, Jamaica, 2016.

\section{DISCUSSION}

Since the identification of ZIKV in Jamaica in January 2016, the virus has spread from Eastern to the Western parishes. The national surveillance system as of September 9, 2016, has identified 5426 suspected ZIKV cases, of which 521 were in pregnant women. Ninety-one cases were confirmed and of these, 36 cases were pregnant. Additionally, 22 cases of GBS have been identified and no ZIKV-related cases of microcephaly have been identified. The leading symptoms among the suspected and confirmed cases were similar which were rash, fever and joint pain. The case definition used by the $\mathrm{MOH}$ identifies more suspected cases of ZIKV and the use of the PAHO case definition of 2016 would have led to $67 \%$ of the confirmed cases being missed (excluding pregnant women) and $6 \%$ missed in pregnant women. Jamaica's findings will help PAHO/WHO in modifying the case definition for this emerging disease.

Zika, Chikungunya and Dengue viruses are in circulation with Zika and Dengue viruses predominating. These circulating arboviruses present both a unique and collective challenge. Dengue fever can be complicated by haemorrhage; Chikungunya with debilitating joint pains and neurological complications including GBS. Zika virus is now conclusively linked to neurological complications including GBS and perinatal microcephaly, with subsequent neuro-developmental paediatric challenges. Clinical and laboratory diagnosis becomes more complex due to the overlap in phenotypic expression. There are unknowns regarding the effects of co-infection(s), or having previous arbovirus infection on the clinical presentation and the sequelae. 
Over the last three decades, the number of dengue cases and the frequency of outbreaks have increased significantly in Jamaica. This shows that Jamaica may now be hyper-endemic for dengue. Chikungunya was introduced to Jamaica in 2014 and currently accounts for the greatest number of arbovirus cases recorded in the last three decades. In that outbreak, $49.2 \%$ of Jamaicans self-reported that they had Chikungunya fever (STATIN 2015, Jamaica Labour Force Survey, unpublished). In 2016, ZIKV was introduced and at September 9, 2016, the number of reported cases of arboviruses is already above total reports for all previous years. Undoubtedly ZIKV will also become endemic in Jamaica. How this disease will evolve remains a mystery given the multiple modes of transmission, high and significant burden of asymptomatic cases, prolonged shedding of the virus in semen and other body fluids, possible infiltration of the blood supply and other factors $(5,26-28)$. Large population-based research studies will be needed to answer these and other multiple epidemiological questions related to adult, perinatal and paediatric ZIKV infections and their complications (29). Virological, immunological and laboratory diagnostics are also rapidly evolving, especially relating to improving sensitivity and specificity while reducing costs of ZIKV testing in populations where Dengue, Chikungunya and Yellow fever viruses are also circulating.

The primary link among all three diseases is the mosquito vector. Vector management and control are crucial to limiting the spread of these viruses. The determinants of mosquito borne disease infection are many. They include beliefs about how the viruses are spread; environmental conditions such as water supply systems, inadequate water supply and poor water storage practices; inadequate vector control programme development; the absence of a critical mass for health education and home maintenance and landscaping practices that promote mosquito breeding. The interventions require a coordinated national, multi-sector community approach for public health policy development, engineering solutions, education, communication and social mobilization. The effectiveness of a national response is limited by the (i) gaps in the scientific knowledge about ZIKV, (ii) the surveillance system receiving only the 'tip of the iceberg' of cases, (iii) testing strategy is restricted to presentations that fit the case definition and unusual but non-severe clinical features which can characterize the outbreak will not be tested.

\section{CONCLUSION}

The possibility exists for endemicity of ZIKV in Jamaica, similar to the situation that already exists for dengue and chikungunya fevers. The national coordinated multi-sectoral, multidisciplinary, collaborative response needs to be heightened to address the multiple challenges for control and management of these viral infections and their sequelae. This coordinated response will necessarily continue to evolve as more information becomes available about these emerging and remerging viruses.
Several dengue and chikungunya fever vaccines now exist (30, 31). Given the multiple challenges to prevent transmission of disease, we recommend, that similar ZIKV vaccines be fasttracked into clinical trials to mitigate the devastating effects of this emerging disease.

\section{REFERENCES}

1. Plourde AR, Bloch EM. A literature review of Zika virus. Emerg Infect Dis 2016; 22: http://dx.doi.org/10.3201/eid2207.151990 (Accessed 10 September, 2016).

2. Centers for Disease Control and Prevention. Countries with active Zika Virus transmission. www.cdc.gov/zika/gov/active-countries.html(Accessed 10 September, 2016).

3. Chan M. WHO Director-General summarizes the outcome of the Emergency Committee on regarding clusters of microcephaly and Guillain Barre syndrome. 1 February, 2016. www.who.int/mediacentre/news/statements/2016/emergency-committee-zika- microcephaly/en/Accessed 10 September, 2016.

4. Zika Virus, Microcephaly and Guillain-Barre Syndrome. Situation Report. 1 September 2016. World Health Organization. http://apps. who.int/iris/bitstream/10665/249597/1/zikasitrep1Sept16-eng.pdf?ua=1 (Accessed 10 September, 2016)

5. Centers for Disease Control and Prevention. Transmission of ZikaVirus. www.cdc.gov/zika/transmission, accessed 10 September, 2016.

6. Geographical distribution of confirmed autochthonous cases of Zika Virus (vector borne transmission) in countries and territories of the Americas, 2015-2016. Pan American Health Organization. http://ais.paho.org/ phip/viz/ed_zika_countrymap.asp (Accessed 10 September, 2016)

7. Van Doorn P, Ruts L, Jacobs B. Clinical features, pathogenesis and treatment of Guillain Barré Syndrome. Lancet Neurol. 2008; 7: 939-50.

8. World Health Organization. Identification and management of GuillainBarré syndrome in the Context of Zika Virus. Interim Guidance. 25 February 2016. World Health Organization. [updated 22 August, 2016; cited 10 September, 2016]. Available from: http://www.who.int/csr/ resources/publications/zika/guillain-barre-syndrome/en

9. Yuki N, Hartung H. Guillain-Barre Syndrome. New England J Med 2012; 336: 2294-304.

10. Sejvar J, Baughman A, Wise M, Morgan O. Population incidence of Guillain-Barré syndrome: a systematic review and meta-analysis. Neuroepidemiology 2011; 36: 123-33.

11. Cao-Lormeau V, Blake A, Mons S, Lastère S, Roche C, Vanhomwegen J, Dub T. Guillain-Barré syndrome outbreak associated with Zika virus infection in French Polynesia: a case- control study. Lancet 2016; 387: 1531-39.

12. Mochida G, Walsh C. Molecular genetics of human microcephaly. Curr Opin Neurol 2001; 14: 151-6.

13. Chiriboga C, Kuban K, Durkin M, Hinton V, Kuhn L, Sanocka U et al. Factors associated with microcephaly at school age in a very-lowbirthweight population. Dev Med Child Neurol 2003; 45: 796-801.

14. Rasmussen S, Jamieson DJ, Honein MA, Petersen LR. Zika virus and birth defects - reviewing the evidence for causality. N Engl J Med 2016; 374:1981-7.

15. Miranda-Filho Dde B, Martelli CM, Ximenes RA, Araujo TV, Rocha MA, Ramos RC et al. Initial description of the presumed congenital Zika syndrome. Am J Public Health 2016; 106: 598-600.

16. Granca GVA, Schuler-Faccini L, Oliveira WK, Henriques CN, Carmo EH, Pedi DV et al. Congenital Zika virus syndrome in Brazil: a case series of the first 1501 live births with complete investigation. Lancet 2016; 388: 891-7. http://www.thelancet.com/journals/lancet/article/PIIS01406736(16)30902-3/fulltext

17. Statistical Institute of Jamaica. Population and housing census 2011. Jamaica: Statistical Institute of Jamaica. [Updated July 30, 2015; Cited 13 September, 2016]. Available from http://statinja.gov.jm/Demo_SocialStats/Newpopulation.aspx.

18. Pan American Health Organization/World Health Organization. Epidemiological Alert: Dengue. 13 November 2012. PAHO/WHO. [cited 13 
September, 2016]. Available from: http://www.paho.org/hq/index.php? option $=$ com_docman\&task $=$ doc_view\&gid $=19302 \&$ Itemid $=270$.

19. Chikungunya Virus. Geographic Distribution. Where Has Chikungunya Virus Been Found? Centers for Disease Control and Prevention [Internet]. [reviewed 3 Aug 2015; updated 12 May 2016; cited 13 September 2016] Available from: https://www.cdc.gov/chikungunya/geo/index.html.

20. Pan American Health Organization/World Health Organization. Epidemiological Alert. Zika virus infection, 7 May 2015. PAHO/WHO. [cited 13 September, 2016]. Available from: http://www.paho.org/hq/ index.php?option $=$ com_docman\&task $=$ doc_view\&Itemid $=270 \&$ gid $=300$ 75.

21. Pan American Health Organization/World Health Organization. Epidemiological Update. Zika virus Infection, 16 October 2015. [cited 13 September, 2016]. Available from: http://www.paho.org/hq/index.php? option $=$ com_docman\&task $=$ doc_view\&Itemid $=270 \&$ gid=32021\&lang=

22. Pan American Health Organization/World Health Organization. Epidemiological Alert. Increase of microcephaly in the northeast of Brazil. 17 November 2015. [cited 13 September, 2016]. Available from: http://www.paho.org/hq/index.php?option=com_docman\&task=doc_vie w\&Itemid $=270$ \& gid $=32636 \&$ lang $=$ en

23. Pan American Health Organization/World Health Organization. Epidemiological Alert. Neurological syndrome, congenital malformations, and Zika virus infection. Implications for public health in the Americas. 1 December 2015. [cited 13 September, 2016]. Available from: http:// www.paho.org/hq/index.php?option=com_docman\&task=doc_view\&Ite $\mathrm{mid}=270 \&$ gid $=32405 \&$ lang $=$ en .

24. Pan American Health Organization/World Health Organization. Guidelines for surveillance of Zika virus disease and its complications. Pan American Health Organization/World Health Organization. Washington, D.C. 2016. [cited 13 September, 2016]. Available from: http://iris. paho.org/xmlui/bitstream/handle/123456789/28405/9789275118948_eng .pdf? sequence $=1$ \&isAllowed $=y$.
25. Duffy MR, Chen TH, Hancock WT, Powers AM, Kool JL, Lanciotti RS et al. Zika virus outbreak on Yap Island, Federated States of Micronesia. N Engl Jour Med 2009; 360: 2536-43.

26. Barzon L, Pacenti M, Franchin E, Lavezzo E, Trevisan M, Sgarabotto D, Palù G. Infection dynamics in a traveller with persistent shedding of Zika virus RNA in semen for six months after returning from Haiti to Italy, January 2016. Euro Surveill 2016; 21(32): pii=30316. DOI: http://dx. doi.org/10.2807/1560-7917. ES.2016.21.32.30316.

27. Bonaldo MC, Ribeira IP, Lima NS, dos Santos AA, Menezes LS, da Cruz $\mathrm{SO}$ et al. Isolation of infective Zika Virus in the urine and saliva patients in Brazil PLoS Negl Trop Dis, 2016; 10: http://dx.doi.org/10.1371/ journal.pntd.0004816 (Accessed 17 August, 2016).

28. Vasquez, AM, Sapiano, MR, Basavaraju SV, Kuehnert MJ, Rivera-Garcia B. Survey of blood collection centers and implementation of guidance for prevention of transfusion- transmitted Zika-Virus infection - Puerto Rico, 2016. MMWR 2016; 65: 375-8. doi: 10.15585/mmwr.mm6514e

29. Christie CDC, Giaquinto C. Unravelling the paediatric and perinatal Zika virus epidemic through population-based research. West Indian Med J 2016 Sep19, doi: 10.7727/wimj.2016.454.[Epub ahead of print].

30. Villar L, Dayan GH, Arredondo-García JL, Rivera DM, Cunha R, Deseda $\mathrm{C}$ et al. Efficacy of a tetravalent dengue vaccine in children in Latin America. N Engl J Med 2015; 372: 113-23; January 8, 2015; doi: 10.1056/NEJMoa1411037.

31. Ramsauer K, Schwameis M, Firbas C, Mullner M, Putnak RJ, Thomas SJ, et al. Immunogenicity, safety and tolerability of a recombinant measles-virus-based chikungunya vaccine: a randomised, doubleblind, placebo-controlled, active-comparator, first-in-man trial. Lancet Infect Dis 15: 581-614; doi: http://dx.doi.org/10.1016/S1473-3099 (15)70112-X. 